\title{
Forestry and Farming System In the Mid-Hills Of Nepal
}

\section{Kiran Dutta Upadhyay*}

"What is common to the greatest number gets the least amount of care. Men pay most attention to what is their own : they care less for what is common"

Aristotle

"Small farmers are held responsible for environmental destruction as if they had a choice of resources to depend on for their livelihood, when they really don't. In the context of basic survival, today's needs tend to overshadow consideration for the environmental future. It is poverty that is responsible for the destruction of natural resources, not the poor."

Geoffrey Bruce

We have had a plethora of articles and analyses about what we are doing and where we are going in the name of sus.

* Mr. Up dhyay is a Lecturer at the Central Dept. of Sociology/Anthropology, T. U., Kirtipur, Kathmandu, Nepal. 
tainable development and conservation. Which has become only official policy. We have to look, inspite of several sincere attempts, why we could not diffuse this notion at grass-roots level. More specifically, we have to look at how rich our people can be in terms of their use of natural resources.

Out of the total land area of the country only 18 per cent is agricultural land and only 37 per cent is forest land. Paradoxically, where agriculture is the major source of livelihood for Nepalese, the growth in agriculture production has remained far from being satisfactory. It grew at the rate of 1.5 percent per annum during the period $1970 / 71$ to $1984 / 85$, which was relatively lower as compared to the population growth rate of 2.66 per cent per annum for the corresponding period. This has resulted in the decline of per capita availability. Because of such phenomenon, encroachment on forest, forest firing and shifting farming are gradually increasing, leading to environmental degradation. Excessive deforestation in the Hills and Mountain is aggravating the loss of life and property by floods and landslides. Fertile soil is being washed out by small and big rivers. People from the Hills are migrating to Tarai because of denudation, floods and landslides there and forest in the Tarai has been also depleted very fast during the last four decades.

Farming is practised under different conditions in the Hills. Crop production is practised in valley bottom land, small plateau along the river banks, and on terraced slopes, about 80 per cent or more of which consists of rainfed upland terraces, ane 20 per cent or less of partially irrigated valley bottom lands along the river banks. Climate and soil vary over short distances because of topography. The agricultural production is characterised by a high man-land ratio. The population pressure on actual cultivated land is around six people per hectare in the Hills. Other characteristics include a great disparity in land ownership, a system of sharecropping which inhibts the motiva tion of tenants, absentee ownership, high rentals, a large number of poorly fed livestock with low productivity, inadequate knowledge of new technologies, ineffective extension services, lack of timely availability of inputs and, finally, traditional method of cultivation with cultural prejudices in some cases. This has resulted in keeping the farmers in low income and in a vicious circle of poverty. Therefore, Hill agriculture is mostly of a subsistence nature and is in a dilemma.

Forest covers some 37 per cent of Nepal's land area and stretches from the lowland's tropical deciduous, riverain forest, below $300 \mathrm{~m}$ elevation to the Abies forest found at $4500 \mathrm{~m}$ in the Himalayas. The total area under forest in the Hills is now estimated to be approximately 2.5 million ha. or less (out of 5.6 million ha. of area covered by forest in the country). Natural forest types reflect the dissected topography of the country and the variability of its climate. Forests between an altitude of about $2,600 \mathrm{~m}$ and the limit for trees at about $5000 \mathrm{~m}$, consists mainly conifers (fir, spruce, blue pine) with some hardwood (oak and hemlock). The forest of the Hills lying between $300 \mathrm{~m}$ and $2,600 \mathrm{~m}$ varies considerably in composition and is scattered in patches throughout the area. In general, at higher altitudes, fir and oak predominate, gradually giving way to chir pine, and species of prunus, Alnus at medium elevations and Sal (Shorea robusta) at lower elevations.

In the Hills, the pattern of settlement and forest use is more fragmented and intermixed. It implies a reduction of 25 per cent in forest area over the past decades. Increasing demand and declining supply of fuelwood has serious ramifications for agricultural productivity.

The mountain ecosystem, once dominated by dense forests, has rapidly deteriorated in recent years because of the interaction of a number of interdependent factors affecting life and agriculture in the Hills. Forest in the Mid-Hills has been converted into bush land. Trees are overcut, lopped and forest floor is overgrazed. The situation is, in fact, worse than what available figures suggest, because many areas of the Hills, now classified under forest, are in fact degraded waste-land with few or no standing trees.

The Seventh Plan recognized the critical nature of 
Nepal's declining forest. It notes that in order to keep pace with curret consumption, reforestation should be carried out at the scale of 100,000 ha. annually, but, in fact, just 50,000 ha. in total were reforested in the past ten years.

Inspite of several national and international efforts, the forest resources is in dicline with more dilemma.

\section{An overview of the Natural Resource Trends and Farming System in the Hills}

Farming systems in the Hills go hand in hand with elevation as proxy for differences of resource availability and resource use. Mainly, I am describing two types of farming systems in the Mid Hills - one at the lower elevation (below $1500 \mathrm{~m}$ ), and the other at the higher elevation (located in - between $1500 \mathrm{~m}$. and $2750 \mathrm{~m}$.).

\section{FARMING SYSTEM AT THE LOWER ELEVATION:}

Villages on the bottom of the Hills and near the bank of the river have relatively more irrigated flat as well as level terraced lands usually cut into the valley side slopes. The land which is more flat and large in size is known as 'Tar', while irrigated, relatively alluvial flat terraces having irrigation facilities during the dry season are known as "Khet", rice is grown in both the types. They are located below $1500 \mathrm{~m}$. In the Hills very few Tars can be located. Virtually, small airports in some of the Hills can be seen on such Tars. Three of such airports are "Rumjatar", "Phaphlu" and "Tumlingtar" located in the Eastern hill districts.

In such surroundings fewer livestock are seen which tend to be tethered and grazed within the vicinity of the households and farmers make compost with animal bedding and forest litter. One can see the fodder trees on the edges of the terraces, in a few cultivated holdings and also on the ediges of the terraces in their courtyard. Overgrazed pastures and shrublands can be seen. Rotations in the cropping pattern which have two to three crops per year are found and there is little access to forest (intact). One of the remarkable features that one finds here is "Goth" (huts for livestock keeping). The area near the ponds, rivers and streams are allocated for "Goth". Its surroundings is called "Besi". Some rich farmers having more than 1.75 ha. of "Tar" and "Khet" lands take their livestock to "Besi" (low elevation) for winter grazing. During this period herders live there. Because of the concentrated agricultural holdings, settlement patterns are also dispersed accordingly.

\section{FARMING SYSTEMS ON THE UPPER ELEVATION:}

In the high elevations villages have few irrigated lands. known as 'Khet", but more widely ci persed rainfed terraces, known as "Bari". The "Bari" terraces, in most of the instances, are outward sloping not properly leveled and relatively more slopy rainfed terraces suitable only for maize and millet. Every year farmers grow two crops of maize, millet, barley, wheat, and a variety of other crops on rainfed Bari below $2300 \mathrm{~m}$. In a very small scale, wheat can be seen in a few Baris. However, wheat even in the "Khet" is found only in a few instances, because wheat farming in the Hills is relatively a recent phenomenon.

There is a fourth type of agricultural slopyland $\left(30^{\circ}\right.$ to $35^{\circ}$ slopes) known as "Pakho" sometimes "Pokho-Bari" which is suitable only for maize.

Farmers usually plant one crop of potatoes or barley buckwheat in the fields above $2300 \mathrm{~m}$. because of the cooler climate, steeper slope, stonier soils. Here, as compared to lower elevation. agriculture is more marginal. Here terraces are often scattered, fragmented, having more parcels and are located at a distance of three or more hours of walking from the farmer's house. Area (surroundings) located above $2500 \mathrm{~m}$. is known as "Lekh", as it is covered by monsoon cloud and has broadleaf evergreen forest. 
Higher villages have a larger number of livestock which they keep away from the village for significant period of the year and are more mobile with household members. Farming is accomplished by keeping livestock on harvested fields for several weeks prior to planting the new crops. Thus, they can deposit dropping to be used as manure and urine in their crop land. Most of the households keep their herds of cattle, water buffalo, sheep and goats in the forests during the time when the fields have crop. During these times and when the animals are on agricultural field, the herder lives in the "Goth". Even when livestocks are in agricultural fields, crop residues are supplemented by fodder cut from forest trees. Fodder lopping (illicit cutting) gradually kills forest trees and grazing browsing prevents regeneratian of the forest trees.

Villages on the upper elevation control large areas of forest $(1000 \mathrm{~m}-2500 \mathrm{~m})$. Here, most of the areas have been converted into agricultural and grazing lands. However, some slopes and steep lands have still preserved forest. Most of the temperate and sub-alpine forest above $2700 \mathrm{~m}$. is being used and gradually converted into shrublands. Herders take livestock to the forest or alpine pastures.

A few households of upper elevation are transhumants who first move their herds to summer alpine pastures and then bring them back through the forest to lower elevation winter pastures in an annual cycle.

Farmers from the lower elevation also collect firewood, fodder, forest materials for cottage and small scale industries, wood for shingles and roofing together with other roofing material, and timber from higher elevation forest.

Here we may find a mixed type of settlement as well as different ethnic groups having their own clusters (Tibeto-Burman ano occupational, untouchable caste).

As we proceed to higher elevation representing the ridges descending from the high Himals, agriculture is supplemented by pastoralism and trade. These villages are inhabited by Tibsto-Mongoloids, viz. Sherpas (Bhotes), Tamangs, Rais, Magars and Gurungs, having their clustered settlement patterns.

The size of forest, Tar, Khet, Bari, and Pakho, and degree of agricultural intensification are the determining factors of the farming system.

\section{LIVESTOCK}

Livestock raising is an integral part of the household economy and of the farming system that supports and supplements crop production and is an additional source of household income. It is also an important source of nutrition, especially for the HIll dwellers, and is closely associated with social prestige and religion. Almost every farm family maintains livestock: cattle, buffalo. sheep, goat, pig and poultry. However, the types of livestock raised vary in terms of ecological belt, ethnicity and the elevations in the Hills. Livestock is a specialized activiry of the mountains, while in the Hills it is subsidiary. Nepal has one of the highest per capita livestock per household in the world and thus has one of the word's highest livestock population per unit of land. A very large proportion of the livestock is found in the Hills with about 60 percent of all livestock concentrated in the middle Hills. Livestock statistics in Nepal are variable and not sufficiently accurate to judge trends in animal population changed with any degree of accuracy.

Forest is also getting declining due to excessive pressure of livestock population. It is observed that more than 40 per cent of the total fodder consumption for livestock in the Hills is from forest. Thus, the decline of forest is also directly related to pressures of growing livestock population. But due to the most pronounced fodder deficit and overstocking, ruminant livestock generally have poor nutrition and are susceptible to diseases, causing the cattle to be unproductive, and resulting in considerable wastage through sickness. Animals are continuously scavenging for a green bite. Inputs into the animal component are straw and fodder, cereal grains, human labor, 
tools and facilities, for grazing. This is how the rural family ecosystem operates; however, it is a neglected aspect of recent socio economic analysis.

\section{LIVESTOCK AND FARMING SYSTEM:}

The farming system in the Hills continues to be a traditional one evolved over centuries. Crop production, livestock and forestry have been closely integrated and interlinked in the farming system, each supporting the other. Livestock are a means of collecting, concentrating and breaking down a large amount of plant material to provide food for the household members, heafs, kids to the farming household and also dung for composting and recycling, and of income to the farming households. Earlier than 1950's sufficient areas of pasture and forest were available and an increasing number of cattle were expected to supply greater quantity of compost to maintain soil fertility. Unfortunately, this situation has changed in recent years. Pressure from rapidly increasing human population has resulted in a general direction in the forest areas, as trees have been cut for fuelwood, and more forests cleared to provide additional land for cultivation. With a dwindling away of the forests many trees succumbed to fodder production-the animal feeding fallen down, finally reducing the livestock productivity. As a result, it has led to decreased availability of compost, reduced crop production, fewer crop residues for feeding animals and finally in the lowering of their productivity, thereby affecting the agricultural productivity and greater encroachment on the forest areas Thus, the vicious spiral has further accentuated the already existing critical situation.

FOREST AND THE FARMING SYSTEM; AND THE NATURE OF FOREST RESOURCES USE (CAUSES OF NATURAL, RESOURCE DEGRADATION):

Nepalese population is dependent on agriculture in which forest sector plays a vital role. The contribution of forestry to agriculture has given birth to the concept of agro-forestry. Forest provides fodder for livestock.
In Nepal, rural poople ( 94 per cent) are dependent on forest resources. The forest supplies fuel to villagers for heating and cooking. Wood has even now remained a dominant domes. tic fuel for rural Nepal. Fuelwood at present provides nearly 87 per cent of the energy in Nepal and 97 per cent in the rural areas. About $540 \mathrm{Kgs}$ of dry wood Is needed per year and per person for cooking and heat. This means about $1 \mathrm{Kg}$. per day per person for cooking, and in addition $1 \mathrm{Kg}$. extra for heating per day per person in winter time. The increasing demand for bio-fuels from forest can be attributed to the population growth, viz. 2.66 per annum.

Timber is another use of forest. Wood for construction is taken carelessly, and the depletion is extreme.

The leaves and wood of trees also play a ritualistically important role, i. e. many Hindu rituals can not be fulfilled without the use of tree leaves and wood for burning.

Irrespective of the form, deforestation, in fact, has not only increased soil erosion, affecting directly crop productivity, but has also made the availability of fuelwood, fodder, timber and other forest products more and more scarce every year. Farmers spend more time and energy to collect their daily requirements.

Inspite of several national and international efforts, the status of rural populace and ecological balance in Nepal seems to be at decline.

The long-term objective of the eco-system related to maintaining the ecological balance should be to protect the environmental degradation and to maintain the balance in the demand for fuel, fodder, and timber with the ability of the ecosystem to supply these products on a sustained basis and finally to raise the agricultural productivity. Hence, it would be necessary to understand the main features of farming system of the Hills. Most of the farming system in Nepol as described above is the interaction as between human resources, livestock, cultivated land and uncultivated land and forest. 


\section{Grassland}

Given the place of livestock in the Hills' agricultural system, the availability and condition of grassland is very significant. Poorly managed grassland can very easily degrade and give rise to serious resource management problems.

Land classified as grasslands consists of:

- heavily degraded forest converted to grassland;

- abandoned cropland used for grazing;

- community grasslands; and

- highland pastures (often seasonal).

Most sources indicate that grassland suffers from mis-management and increasing degradation.

Grasslands are prone to overgrazing, severe reduction in vegetative cover, compaction of soil and serious soil erosion.

The range of types of grassland includes abandoned terraces prone to uncontrolled grazing, especially by small ruminants, overgrazed degraded forest lands converted into unprotected grazing areas and seasonal pastures at higher altitudes. The information available on grassland is rather inadequate.

\section{SOCIO-ECONOMIC FACTORS FOR NATURAL RESOURCE DEGRADATION:}

The most direct socio economic influence is simply the size of the population in the Hills and the migration trends that account for net population growth. Obviously, increasing population affects the number of mouths to be fed, the number of meals to be cooked and number of non-farm activities that might consume natural resource commodities,

The second most obvious socio-economic factors that influences the resource use are incomes and price (forest resource-use falls within the cash economy). A more complex and varied set of socio-economic factors govern the decisions about natural resource management use and how specific demands for resources are met. These include cultural determinants among different ethnic groups, the role of women in rural decision-making and property rights.

It $\mathrm{C}$ an be assumed that these factors and incentives are also the factors of the natural resource degradation. The other socio-econo mic factors responsible for degradation include:

a) forest de pendent local household based cottage industries as well as other small industries and manufacturing processes in the Hills;

b) tourism, and

c) Hill-Tara i and Valloy-plains linkages.

This can be illustrated by dealing briefly with two of the socio-economic factors responsible for natural resource degradation.

\section{INCOME PRICE AND MARKET:}

The Hill economy is that the villagers' cash income is extremely low and in some cases to supplement their household expenditure natural resource commodities are traded in for cash. A major source of cash income in the Hills is known to be remittances from overseas or pensions and salaries from services in the British or Indian armed forces. Thus, this source is supposed to contribute substantially to the Hill economy. In addition, sale of firewood also constitutes a major source of income to supplement the household expenses of the weaker section of the Hills. It is also evident that nationally, fuelwood prices rose by 15 per cent in real terms in the 1970 s.

\section{PROPERTY RIGHTS AND LAND TENURE:}

Property rights and land tenure are also the significant factors that influence the decision of the villagers about using the resource-base to meet their requirements. These are relevant to decisions about private and public lands. Community property rights in some areas continue to be exercised. However, in many areas the result has been that in the absence of proper community management, the forest has become an open access 
resource in which neither individuals nor communities exercise exclusive property rights. Much grassland is owned by the government, but treated more or less as open-access property.

\section{INSTITUTIONAL DEVELOPMENT IOR FOREST PRO} TECTION:

Because of the growing problems of protection and management of forests, governmental and institutional efforts were introduced to supplement traditional conservation practices. Because they were often too ambitious, these agencies did not always attain the stated objectives. Nevertheless, there are many example of success. One of the first major initiatives towards institutionalizing natural resource conservation was undertaken in 1934 with the establishment of "Ban Janch Adda", forest office for protection and harvesting Tarai forest. This office continued until 1956 when it was replaced by the Office of Chief Conservator. This was the beginning of forest management and development in terms of demarcating and harvesting commercially valuable forest stands in concert with afforestation programs and construction of fire lines and forest roads.

In 1951, the Ministry of Forest was formed, which ten years later, became the Ministry of Forest and Agriculture (now known as Ministry of Forest and Soil Conservation). The Forestry school was established in 1950 under the aegis of the Department of Forest to commence the training of forester's at the technical level. With the passage of the Forest Nationalization Act in 1957, the traditional forms of resource conservation (as mentioned above) ceased to function.

In 1971, the Forestry school became the Institute of Forestry under Tribhuvan University. During the 1970's, Intergrated Rural Development.Programs were undertaken all over the country. In some cases, though with varying degrees of success, these programs were addressed to conservation issues. In 1976, the National Forest Plan was prepared by His Majesty's Government. The plan gives emphasis to the need for conservation, with specific reference to controlling landslides and soil erosion. Perhaps most significantly, it speaks of the need for community participation in the development and protection of forests. The Department of Soil Conservation and Watershed Management, as it is now known. was established in 1974 as the Department of Soil and Water Conservation. One of the resource conservation initiatives established to date is Community Foresty Program. The basic philosophy underlying the program is to encourage the active participation of villagers in forestry and related conservation project. In 1987, the Division of Environment and Resource Conservation was established within the Planning Commission. A master plan for the forestry sector was prepared in 1988 setting out targets for bringing Nepal's forest under sustainable management to meet demand for forest products and reverse the trend of overusing the productive stock.

\section{ADVERSE EFFECT OF THE GOVERNMENT PROGRAM:}

The 1957 government legislation of nationalising the fo:est removed people's responsibility for preserving and mana. ging the forest resources. in the eyes of the public the forest ceased to be owned property and this resulted in the increased destruction of forest resources. A few years ago, the publicised motto was "Green forests are the wealth of Nepal" but now this has become obsolete. People recognize forests as common property and free goods. They think they are entitled to enjoy the benefits of the forest, but they do not realize they have to put efforts to sustain the forest, Therefore, heavy consumption of firewood, use of fodder to sustain excessive livestock population and the practice of uncontrolled and unsupervised grazing, illicit cutting and other associated activities have been fully responsible for the disappearance of forest resource. The statistics available indicate that with present usage and increased demand due to growing population, accessible forest in th $\theta$ Hills may disappear within 14 years.

Government policies regarding better forest resource management date back from 1957 when the first "Forestry Act" 
was enacted and implemented. Under this Act, the Nepalese government nationalized all the forests. Prior to that, in most of the villages there existed a few traditional rules for forest management and protection. However, government nationalization of the forest had adverse impact. Unfortunately, the Act was misunderstood by the people, who believed the Government had deprived them of their right to free access to and use of forests. Gradually, the traditional rules regarding forest management and protection began to fade away and people did not feel any responsibility for themselves towards maintaining the forest. Then, firewood, fodder and timber were collected indiscriminately and the rate of destruction was significantly accelerated. Legislation of the government became entirely ineffective because people's attitude changed. They started to think forest as everybody's property is nobody's property.

The National Forestry Plan of 1976 was the first attempt to innitiate comprehensive forest development in Nepal. The plan emphasized the importance of improving the productivity of the rorest and stressed the need to initiate the Community Forestry Program to meet the local demand of forest products that supposedly managed the forest resource as well as supply the community needs. In order to supplement the plan and to involve community (local people) in the protection and regeneration of the forest, "The Forest Act of 1957" was amended in 1977. This amendment allowed private forestry and community sanctions against practices affecting the forest. Among others, the national forestry policy aimed at preserving and maintaining forest.

APPEARANCE OF COMMUNITY FORESTRY PROGRAM (A RADICAL APPROACH):

In fact, the high rate of forest destruction and negligible rate of afforestation made the government realize the need to manage forest through community participation. Since the nationalization of forests was unsuccessful, a radically new approach has been started with the objective of returning ownersnip of the resources to the people or the communities,
Community Plantation and Cominunity Forest are the community owned and monaged forests. The new policies concentrated on planting on bare land and bringing existing forest under better management through community participation. Community forestry is the forestry for the people and by the people. Satis. fying basic needs of the forest products, conserving fuelwood by introducing improved wood burning stoves, promoting selfreliance in the local forestry and reducing environmental degradation have been the basic objectives of community forestry. This project began in mid-1984. Now it has its program covering $37 \mathrm{Hill}$ districts. Financial support to $\mathrm{HMG} / \mathrm{N}$ for $\mathrm{CF}$ activities is provided under World Bank IDA credit. Technical assistance at the centre is provided by FAO through UNDP.

Here it is important to explain some of the operational guidelines for implementation of the Community Forestry Program of the government for the local people.

\section{DEFINITIONS AND WORKING PRINCIPLE:}

\section{COMMUNITY PLANTATION:}

Any government forest land, devoid to trees or in which only scattered trees or shrubby vegetation are left and which HMG has notified for forest development through reforestation.

Barren land, or any public land of which at least two thirds of planting can be awarded to the local community for community plantation at their request. Each Village Development Committee henceforth VDC, a revised name of the past Village Panchayat after the abolition of Panchayat System, and which is the lowest administrative unit of several villages with a total population of $2,000-5,000$ persons. Community Forestry activities, carried out mainly at this level, are entitled to up to 125 ha. of community plantation. While most community plantation products are distributed free to the participating community, income from any sales goes to the treasury of the local VDC. 


\section{COMMUNITY FOREST:}

It refers to any government forest which HMG has notifie $d$ for management and conservation. Government forest land needing the protection or enrichment of planting can be provided as Community Forest at the Community's request. Each VDC is entitled to acquire up to 500 ha. of forest land for Community Forest. Seventyfive percent of income from the sale of timber goes to the VDC, and the remainder to the Government. All other products such as fuelwood, fodder, leaf litter and others are made available free of charge to the participating local communities according to the approved management plan.

Even degraded forests of Nepal show remarkable potential for natural regeneration. The greatest challenge to the project now is how to tap this potential through the use of an appropriate management.

\section{OPERATIONAL PLAN:}

It refers to a formal agreement between the users, the Forest Department and the VDC, which specifies all aspects relating to the management of a specified area of community plantation or Community Forest, including the regulation of utilization and the distribution of benefits. An operational plan is legitimised by the endorsement of the representatives of the user group committee, the VDC, and the District Forest Office.

\section{MANAGEMENT PLAN:}

District Forest Controllers (DFC's) and Community Forestry Assistants (CFA's) provide technical guidance on good forestry practices, but people decide what trees to plant, when and where to plant them, the organization of planting and management of forest outputs and others. The management plan thus becomes step to the villagers' plan and is formalized by a contract signed by the VDC's representattves, the Chairman of the Forest Committee and the DFC.
National Forestry:

It includes all forests except those designated otherwise.

User Group:

The group of people. generally defined on a settlement or household basis, which is entitled to manage and utilize a community plantation or Community Forest, is called user group. Generally a user group would include those households which have long since been utilizing a specified patch of forest to meet their forest product needs.

User Group Committee:

It has an executive committee representing all segments of the user group formed by popular decision. The duties. responsibilities and power of the user group committee will be specified in the operational plan as agreed between forest department staff, VDC and users' committee. Preferably one third of the members of the committee will be women.

Some Bottlenecks in the Process of Implementation:

The following are some of the possible hindrances in the process of implementing government program in the sector of Forestry.

a) The legal basis under CFDPs consists of the Commuuity Plantation and Community Forestry rules. However, the amount of land that a VDC may acquire for $C P$ and CF is fixed regardless of the VDC area, population and land use within the VDC.

b) The field visit supports that majority of the farmers prefer forest species which produce good quality firewood and forage. The species which are seen most successful in reforestation are "Chirpine" at the lower elevation and 
"Patula pine" at the higher elevation. The desired broadleaved forage and firewood species have had limited success. The planting of pine which is more likely to happen may have adverse effect on the villagers. Even today it can be heard from farmers that pine trees are good for the government, but not for them.

c) There has been failure on the part of line-agencies and project administrators to recognize the necessity of assisting in the implementation of multi-sectoral population programs and effectively involving women in Forestry.

d) There is lack of an adequately coordinated effort at the ministerial, departmental, project and local level communities.

e) Inadequate institutional and organisational capacity at the regional, district and village levels for delivering and administering the programs and follow-up services on a regular basis.

f) Forest management in the Hills is universally hampered by poor communication and extension services.

g) Community Forestry Development Program has set a precedence of paying for plantation establishment cost and the salary of watchers. This has the disadvantage of reducing the level of Community participation. In other words, it decreases the degree of community participation, and supports people's attitude that "it is a government program."

h) Though it is the women whose daily activity centers on the use of basic resources - wood, water, land, fodder, crop and livestock, the production of food, shelter, energy and clothing and the concern for human health and family wellbeing, almost without a few exception, the line-agency staff at the village level is a male. As women are the main collectors of firewood, fodder and water, it is obvious that the National Conservation strategy, to be successful, must clearly involve rural women. To accomplish this task, it will be necessary to reach women at the farm household level and this is lacking.

The link between conservation and population is direct. Unchecked population growth will seriously undermine conservation as well as development strategies. Hence efforts should be made to extend literacy to the maximum among the rural Nepalese and, thereby, change their attitudes towards the process of forestry and development.

Existing Private Group and Their Resource Management Practices:

A Case Studies on Community Forest and Irrigation Management.

Case No. 1

In the Hills of Dang District (Mid-Western Hills of Nepal), approximately $10 \mathrm{~km}$. northeast from Ghorahi, lies Saiga Village In ward No. 2 of this Village Development Committee there are 60 households comprising several different ethnic groups. Magars (Tibeto-Burman Mongoloid) are in majority. There the local people by themselves are protecting their nearby forest. The exact area of forest land is not known. The users' committee (comprising village dwellers) have formed an organization to carry out the work necessary for forest resource management. The committee is headed by the Chairman (Adhakshya), chosen by the villagers. They have contributed Rs. 20,00 annually from each household. With this money, they hire a Kotwal (watchman) for the protection of the forest. The forest has been providing fodder and fual to their household. Based on social sanctions, if someone tries to violate the forest committee management rules, the forest committee immediately holds a meeting and the guilty farmer is fined. The fine is fixed by the committee. Money thus collected is 
deposited in the village school's treasury and is used for the school.

\section{Case No. 2}

In Dubidanda Village Development Committee at Jaspur village of Rolpa District (western Nepal), a similar community forest management scheme is in existence. In this village there are $\mathbf{2 5 0}$ households. The population is composed of Magars, Brahmins, Kshytriyas and occupational caste Kamis (untouchable). The villagers here collect paddy and rice from the households to pay the forest watcher renumeration for his services. The watcher is employed by the village users' committee. The users committee is headed by a chairperson, who is chosen by the villagers. There is a well-established sanction according to which if someone tries to steal forest products, he/she is fined by the committee. This amount is also deposited in the village school's treasury. Depending on the nature of the offence, a person can be fined up to Rs. 150.00 at most.

Case No. 3

Rampur Village Development Committee is located 12 $\mathrm{km}$ from Ghorahi (western Nepal) in the eastern part of Dang District. The Balim Khola (river) irrigation project covers ward Nos. 4, 6 and 7 of Rampur Village Development Committee. The project area is linked by a seasonal dirt road to Ghorahi, the district headquarters of Dang District. The project area is bounded by the Babai river in the South, the Bhote Dhaha and Balim Khola in the North, the Chepa Khola in the east and the Balim Khola in West. The command area has north to south facing slopes.

The total estimated command land area of the Rampur irrigation system is 253 hectares, of which 136 hectares area is lowland and the remaing 117 hectares upland. The average land holding size is 1.125 hectare per household. Persons of the
Brahmin caste own about 70 per cent of the land, and the Tharus, the (Tharus are Mongoloid), the first settlers of Dang valley, own about 15 per cent. The remaining is divided among various other castes with the smallest per cent (less than 1 per cent). e. g. to the Kamis (blacksmiths; also untouchables).

The rehabilitation of this irrigation project was undertaken in 1985 by the local irrigation users' committee with assistance from the Agricultural Development Bank of Nepal, under its SFDP program, and technical assistance from CARE/ Nepal under the phase I Rapti Project (A USAID funded Rural Development project). The assistance from CARE/Nepal paid approximately 50 per cent of the total project cost. This was primarily in the form of construction materials, tools and equipment, logistic services, technical and managerial support (this amount is funded 80 per cent by Rapti IRDP and 20 per cent by CARE). The $A D B / N$ has provided a loan for 30 Per cent of the total project cost and the remaining 20 per cent was provided by irrigation Users' Committee through local peaple's participation.

People's Participation:

The Rampur Irrigation System uses a system of labor contribution, locally known as Kalami. The Kalami consists of the following four categories of labour contribution by the farmers:

4 Kattha -3 bighas $=1$ labor $/$ day;
3 bighas -6 bighas $=2$ labor $/$ day;
6 bighas -9 bighas $=3$ labor $/$ day;
and bighas -12 bighas $=4$ labor $/$ day.

If the allocated laborers do not come during their turn for the assigned work they pay a fine at the rate of Rs. 15-20 per day, per head. However, when emergency maintenance is needed all farmers have to come to repair the damaged canal. Regular rotational work is maintained for day to day operation

$* 1.5$ bighas $=1 \mathrm{ha}$.

20 ropani $=1$ ha. 
of the canal. Emergency work is necessary during the monsoon when heavy rainfall with flood occurs and damages the intake dam and canal.

\section{Local Management Groups (Water Management):}

The Rampur Small Farmer Irrigation System is a good example of existing community-managed irrigation which has a formal organization to carry out the necessary works for the irrigation system. The organization committee has a chairman (adhyaksha), vice-chairman (upadhyaksha), three members and one watchman (kotwal) nominated by the village meeting which is held once a year.

The chairman and the vice-chairman are responsible for the allocation of water to the fields, arranging meetings, resolving conflicts, managing and supervising the works at the canal, whereas the members keep the attendance record of the farmers at work, the accounts and the minutes of the meetings. The Kotwal is responsible for patrolling the canal every day during the monsoon season. He informs the chairman and vice-chairman and calls the people for repair and maintenance work, if the canal has been damaged. The Kotwal gets Rs, 1800 per year from the villagers as his renumeration. The existing canal was constructed by villagers many decades ago. The rules pertaining to water allocation are based upon the availability of water in the canal. If the water is not sufficient in the canal, farmers use it on a rotation basis. The whole command area has been divided into 3 blocks (Tols).

Dispute Resolution:

A few farmers have tried to steal water due to the insufficient supply of irrigation water at the tail end of the command area. This has led to conflict which has arisen because of water availability differences among those at the head and those at the tail end of the canal. In such cases the committee 22 hoids a meeting and the offending farmer is liable to a fine fixed by the committee.

Forest Resource Management:

Farmers of the Rampur irrigation command area have a forest of about 40 ha. of land area located near the main canal intake and is managed by the water management committee. It was observed that the cash income from this forest in 1985 was about Rs. 2,200. This money is used for the repair and maintenance of the canal. Forest grass are sold by the committee to farmers every year. It is the main source of income from the canal. This forest has been under the control of the same water users' committee for the past 10 years.

\section{Existing Technology:}

Wherever the above groups have evolved appropriate and efficient management system, they have generally operated outside the Government support structures and had no access to modern production technology. The observed irrigation projects lacked in modern technology for crop production. Local institutional support is weak; as a result, farmers cannot get access to improved seeds, chemical fertilizers and improved technologies.

Applying The Lessons of Traditional Group Management:

These case studies of different groups provide some insights into group behaviour which can be used for project design. From these case studies, it is evident that traditional local groups are in existence in the Hills of Nepal. They use traditional methods for managing a variety of activities. Since those groups provide a model for local organization and common resource management, projects \& $\mathrm{HMG} / \mathrm{N}$ need to recognize their importance and support them by providing technical know-how through extension services so that they can be more effective in their activities. Moreover, as discussed 
above, the existing traditional groups could be incorporated into Small Farmer Development Program and supported and strengthened in their traditional functions.

\section{Social Analysis:}

The need for development is most acute in the Hills of Nepal. The population density per unit of cultivable and grazing lands and number of livestock are extremely high. However, farm incomes are low and food production is far below the acceptable consumption level. The low level of per capita agriculture, forestry production and livestock productivity have become so pervasive as to threaten the people's existence.

The use of the females as village extension field assistance in agriculture, livestock and forestry will provide farm women easier access to goods and services. Women should be approached together with their male counterparts. Although women may be reluctant to attending their first meetings of a grass-root level committees, it can be hoped that they will gradually come out and start realizing their potentialities to cope with the new demands of time.

People's participation in planning, implementation, decision-making, control and in benefit sharing of rural development activities should be encouraged not simply by asking for farmer's labour contribution (Shramadan). The local private group may work as an appropriate channel for the technological dissemination and diffusion process. This Will reduce social distance and communication gaps between people and the programs It is equally important to involve the local leaders and key personnel in the village to reach the grassroot levels. For this, leaders should be chosen as motivators from different ethnic groups, castes and socio-economic strata for the maximum acceptibility of the program. In this way, the leader gains encouragement, confidence, recognition and prestige, and hence, the programs can be easily acceptable to the rural people.

\section{Conclusion}

In the Hills of Nepal, there are several private groups already managing their community forest resources; these group need to be identified and incorporated into a government/non government development program and be assisted in undertaking further afforestation and forest protection activities. In this regard, emphasis should be given to reinforce the program by establishing contact with the chosen representatives from such local groups. While supporting community forestry, village leaders would be a focal point. Training should be provided to such leaders in community forestry and forest resource development. Training is also needed in preparation of Community Plantation and Community Forest activities. Higher priority should be given to fodder tree development in collaboration with the Livestock Department.

Innovation attributed with advantage, simplicity, comp atibility, trainability and observability significantly influences the farmer's decision-making process. Moreover, leadership plays a key role in these issues. It would be worth using the local lead. ers from the several existing private groupes from different ethnic strata in the region as a channel for the dissemination and diffusion of the "forest ethic".

The local people should respect forest and voluntarily keep off their animals from encroaching upon plantation areas. The success of sustainable development of the forest depends very much on village people's understanding why forest must be conserved. Disseminating this information is a formidable task as it requires reaching a population which is largely illiterate

The success of the community forestry program has been largely dependent on the interest of village people and their motivation to contribute to the program. Hence, efforts should be made to adapt basic community attitudes to the use and protection of forests. 
The religious forests in some areas are in good condition because they are respected and protected by people in their vicinity. It has religious significance to them There is a belief that in such area there is "Ban-Kali" (forest goddess) In many of such forests people go for worship. If some of the forests could be channelled towards religious forests by constructing temple in problematic areas, perhaps forest conservation would become easier and simplified.

In addition to forestry, there are several other sectors where assistance is needed. For example, agriculture, livestock health, family planning education and others are the primary areas. Even if it is not possible for a project to incorporate some or all range of these areas, a sound coordination should be made mandatory for all the other line agencies operating in villages. The challenges are both interconnected and interdependent requiring comprehensive approaches and popular participation.

Development means that Nepal has to meet the needs of quality of life of its people and of the future generation; hence, sustainable development and conservation must be firmly embedded in indigenous social, cultural, religious and economic systems in the society. However, it is not as easy or straightforward process. Painful choices have to be made. Therefore. sustainable development must rest on political will and the capacity of the nation to translate it into necessary action.

\section{Notes}

The present article is the outcome of a research proposal on a similar topic I prepared while working at the Department of Social Antropology at the University of Bergen, Norway (Aug.-Oct. 1990), in the capacity of a Visiting Scholar from Nepal. Besides, this article is based on the author's several field works in the mid-Hills of Nepal between 1989-1990 while working for different agencies.

I have discussed some of the issues incorporated in this article with Prof. Gunnar Haaland, Head, Dept. of Social Anthropology, Universiry of Bergen, who made insightful comments and helpful suggestions on an earlier drat of the paper. I would like to express my sincere, gratitude to him. I owe intellectual support from the University of Bergen, Norway.

The authors whose work I have frequently consulted include M. C. Regmi, T.B.S. Mahat, K.K. Pandey, D.D. Bhatta, H. R. Rajbhandary and S. G. Shah, R. B. Singh, S. C. Jain, Gro Harlem Brundtland, David Seddon, J. R. Dunsmore, W. H. Fleming, D. A. Gilmour, D. M. Griffin, K. P. Shepherd, Jenkin and Baired, W. J. H Ramsay, Geoffrey Bruce, Piers Blaikie and Harold Brookfield, and Garrett Hardin and John Baden. I express my thanks to them In preparing this article, I have also referred to the reports prepared by National Planning Commission, Kathmandu, the Central Bureau of Statistics, Kathmandu, the CFDP/HMG/N, Kathmandu, the APROSC, Kathmandu, the Dept. of Food and Agricultural Marketing Services, Kathmandu, the Nepal Rastra Bank, Kathmandu, ICIMOD, Kathmandu, Nepal- Australian Forestry Project, Kathmandu, the LRMP, Kathmandu, the FAO, Rome, the World Bank, Washington D.C., Asian Development Bank, Manila, and Our Common Future-The World Commission on Environment and Development, New York.

However, the responsibility for the ideas and the overall organization in this article lies with me, the author. 